the British Association, he has visited Canada, Australia and South Africa, and is otherwise widely travelled. Sir Albert's election to the presidency of the British Association will be welcomed by all men of science, especially botanists and geologists.

\section{Cambridge Meeting of the British Association}

THE meeting of the British Association which has just closed will long be remembered by all who attended it. At the first meeting of the General Committee, it was agreed to form a Division for Social and International Relations of Science (see p. 380), which may well prove a vital step in the history of the Association. Lord Rayleigh's address was received with much enthusiasm, and a specially warm welcome was given to Sir J. J. Thomson, who moved a vote of thanks to the president for his address, and also to Dr. G. D. Birkhoff, past president of the American Association for the Advancement of Science, who, as spokesman of the delegation from his Association, expressed his desire to see active co-operation between the British and American Associations in the cause of international friendship. The customary announcement at the close of the inaugural meeting, made by Dr. O. J. R. Howarth in the absence of the general treasurer, Lord Stamp, of the number of tickets issued for the meeting, showed that the attendance, 2,795, while not a record, was highly satisfactory. The services of broadcasting were utilized to bring the Association's activities before a wider audience in Great Britain and also in the United States. Prof. Allan Ferguson broadcast an account of the opening meeting through the B.B.C., while on August 19, Lord Rayleigh and Sir Richard Gregory were 'interviewed' before the microphone by Mr. Watson Davis, director of Science Service, and the 'interview' broadcast in America.

THE setting at Cambridge for the meeting was of course ideal, and the University and individual colleges showed their traditional hospitality. In addition to the discussions and papers before the several sections, members had an opportunity of inspecting an exhibition of old and historic scientific instruments, which appropriately included apparatus used by Sir J. J. Thomson and by Lord Rutherford, of seeing demonstrations and exhibits of gold films produced by Prof. C. S. Gibson and his collaborators, and other more 'sectional' exhibitions. The officers of the Association who have been elected for 1939 are as follows : President, Sir Albert Seward; General Treasurer, Prof. P. G. H. Boswell ; General Secretaries, Prof. F. T. Brooks and Prof. Allan Ferguson; New Members of Council, R. W. Allan, Prof. F. E. Fritsch, Sir Richard Gregory, Prof. C. Spearman and Dr. C. R. Fay. Future places of meeting of the Association will be Dundee (1939), Newcastle-on-Tyne (1940), Belfast (1941) and Birmingham (1942).

\section{Impressions of Cambridge}

A CORRESPONDENT writes: "Cambridge is the best of all places for the British Association to meet. There was an air of activity and exhilaration throughout the week, and the organization was carried out with extraordinary smoothness. There were almost too many receptions, dinners and garden parties; perhaps one could wish for a little more time for those discussions behind the scenes which are the most valuable feature of these gatherings. The great novelty of the meeting was, of course, the formation of the Division for the Social and International Relations of Science. It was astonishing and encouraging to find the project so enthusiastically received by the widest variety of scientific workers. It has lit up many people's imaginations, and given them a chance to devote themselves intelligently to something which offers a hint of usefulness in an increasingly lunatic world. Perhaps the shadow of the world outside has never hung so menacingly over a scientific meeting; many there felt that all they cared for intellectually might have vanished before long. It was noticeable that the most eager supporters of the new Division were often those whose own research happened to be particularly 'pure'. Those who complained in private that the cobbler ought to stick to his last usually turned out to be engaged on semi-applied research. It is, for example, interesting that the more abstract kind of physicists tend to be far more socially interested than people busy with traditional chemistry."

"DARWIN's was easily the most exciting presidential address, and a model which other sections might usefully study. It had the great advantage that the intelligent layman could listen to it and not waste his time; and yet it also contained ideas enough to set professional scientists and philosophers arguing for weeks. Childe's and Southwell's were also nice pieces of work, and Griffith Taylor's highly entertaining. For pure science, Blackett's Saturday morning talk on cosmic rays was unsurpassed. The trouble is, one wants to go to so many lectures that are taking place simultaneously. But still, an energetic person could have heard something from Wells, Bohr, Darwin, Keynes, Blackett, Shapley and Huxley-which is not such a bad bag for a week's holiday."

\section{Art at the British Association}

A COLLECTION of photographs taken by members of the scientific delegation from Great Britain to the Indian Science Congress Association's jubilee meeting in January of this year was exhibited in the reception room of the British Association at Cambridge. Some of the photographs were of scientific personalities, others of Indian scenes and inhabitants, whereas several gave beautiful impressions of certain wellknown Indian buildings at night, flood-lit and illuminated. A very pleasing innovation at this year's meeting, too, was the exhibition of works of art by members of the Association, which demonstrated very clearly that genius is not confined to a single avenue of interest. Many outstanding men of science are known to be accomplished in one or other of the arts, especially music, but this exhibition must have proved a pleasant surprise to many. Well over a hundred examples were exhibited, the chief among them being oil and water colour paint. ings, though examples also of ware, metal-work and 
hand-printing and weaving were on view. The arrangement of the exhibition would have reflected credit on the Royal Academy itself. All three members of the Bragg family have clearly found the painter's palette a valuable means of utilizing the little leisure at their command. Sir William Bragg, president of the Royal Society, showed an attractive study of aloes, while landscapes were also exhibited by his son, Prof. W. L. Bragg, Cavendish professor of physics in the University of Cambridge, and by his daughter, Mrs. Carol.

Major C. E. S. PHILlips, secretary of the Royal Institution, and Mrs. Phillips, are known by many to be artists of considerable taste. Between them they showed six of their many paintings, one of them being "On the Purbeck Hills", by Major Phillips, which was exhibited in this year's exhibition at the Royal Academy. A beautiful interior of the Cathedral Church of Christ, Oxford, was exhibited by Emily Vaughan Jenkins. One of the most interesting exhibits was a portrait of a spinster by Joyce Gardiner. The slightly embittered and very grim expression made the portrait live, and the title "Frustration" made the picture itself. Three landscapes by the late Dr. William Bateson, president of the British Association in 1914, and two by Mrs. Bateson showed an obvious love of rugged scenery. Three very beautiful paintings executed by the late Lady Robertson during the meeting of the British Association in Canada in 1924 were exhibited by Sir Robert Robertson, formerly Government Chemist. E. N. Willmer, lecturer in physiology in the University of Cambridge, is known to spend much of his holiday periods painting landscapes; here he showed three examples of what is clearly a successful and enchanting hobby. There is also a good portrait of Dr. F. F. Blackman, emeritus reader in botany in the University of Cambridge, by one of his colleagues, G. E. Briggs. Another by Briggs-“Cineraria"besides being a poem of colour, also brings out the plant physiologist in the painter. The wilting of the leaves and the florets is strikingly natural.

\section{Fossil Anthropoids in South Africa}

FUrTHER discoveries of the fossilized remains of anthropoids in South Africa, which were announced on behalf of Dr. Robert Broom of the Transvaal Museum during the meeting at Cambridge of the British Association (see p. 377 of this issue of NATURE), constitute an addition of the first importance to the evidence relating to the early history of man and his precursors which has been accumulating in South Africa since the discovery of Rhodesian man in 1921 and the later discovery in 1925 by Prof. Raymond Dart of the Taungs skull, Australopithecus africanus. The doubts which had been expressed whether the latter might not be a young chimpanzee or gorilla, and not, as Prof. Dart maintained, more closely related to the human stem than any fossil anthropoid then known, may be regarded as having been finally resolved by Dr. Broom's discovery of the Sterkfontein skull two years ago, to which he gave the name of Australopithecus transvaalensis, but for which his later discoveries now recorded lead him to adopt the significant nomenclature of Plesianthropus, expressing not only its generic difference from Australopithecus, but also its even closer relationship to man in the scale of development. This, however, does not close the tale of remarkable additions to our knowledge for which we are indebted to Dr. Broom. The story of how he rescued from the dangers of oblivion the fragments of still another and even more important relic, will command a tribute of admiration from all for his acumen and persistent energy in the pursuit of scientific discovery. He has been rewarded by the acquisition of what must be regarded as the most important piece of evidence now in existence relating to the evolution of man's ancestry. From fragmentary bones of the skull, the teeth, and the reconstruction of missing parts from the matrix, Dr. Broom has been able to reconstruct the Kromdraai skull, now classified as a new genus, Paranthropus robustus, and not merely coming closer in certain details to man than any previously known fossil anthropoid, but actually in line with man. Equally important is Dr. Broom's conclusion as to its dating, for he is now able to say, subject to further geological investigation, that while Australopithecus is regarded as probably Lower Pleistocene, the Kromdraai skull is Middle, and the Sterkfontein skull Upper Pleistocene.

\section{Russian Astronomers}

The Polish journal Acta Astronomica, in its July issue, states that the following members of the staff of the Pulkovo Observatory have been imprisoned: I. A. Balanovsky, N. I. Dneprovsky, B. P. Gerasimovič (director), P. I. Iaschnoff, B. W. Noumeroff (director of the Astronomical Institute at Leningrad, who is believed to have been shot), N. W. Zimmermann. The Editor of Acta Astronomica states that it would give him great pleasure to be able to refute this statement, a sentiment which we are sure scientific workers everywhere will echo.

\section{Backward Peoples: a Proposal from Holland}

The Netherlands Commissie voor Internationale Natuurbescherming (Netherlands Committee for the International Protection of Nature) has prepared through its recently constituted Committee for the Preservation of Primitive Races a general statement of the problem with special reference to the primitive peoples of the Dutch possessions in New Guinea. To this are added some suggestions as to how best to deal with the difficulties which will arise, or have already arisen, if and when peoples living in the stone age, who in some instances previously were not even aware of the existence of the white man, are suddenly brought into contact with the blessings (aeroplanes, motor-cars, radio) and the curses (alcohol and venereal disease) of Western civilization. A useful point is made, frequently overlooked, that an even greater danger than the white man in the matter of exploitation is the neighbouring native people of slightly higher culture which has assimilated or acquired some of the elements of white civilization. This statement of the problem is restrained, but well informed. Its 